\title{
Monitoring urban storm water: facing climate changes in a Mediterranean coastal city
}

\author{
N. Veloso ${ }^{1}$, P. Cruz ${ }^{2}$, H. Carvalho ${ }^{1} \&$ M. Moreira da Silva ${ }^{3,4}$ \\ ${ }^{1}$ Faculty of Sciences and Technology, University of Algarve, Portugal \\ ${ }^{2}$ Portuguese Environmental Agency (APA-ARHAlgarve), Portugal \\ ${ }^{3}$ Institute of Engineering, University of Algarve, Portugal \\ ${ }^{4}$ CIMA Centro de Investigação Marinha e Ambiental, \\ University of Algarve, Portugal
}

\begin{abstract}
In the actual global climate change scenario, Mediterranean cities are particularly vulnerable to floods and droughts, destabilizing the urban water cycle. During the intense precipitation events, more than in normal rainfall scenarios, the resulting diffuse pollution can be a major threat to the natural ecosystems and human health. Therefore, the characterization of the urban storm water runoff is considered of the utmost importance to the region, and was the main objective of this work. With this purpose, a monitoring plan for urban storm water of Faro (Portugal) was developed. Representative sampling locations, frequency of sampling and analytical parameters were defined. A major storm of the 2014-2015 wet season was monitored. The analytical parameters were TSS, BOD, COD, pH, Conductivity, TN, TP, Ni, Cd, Pb, Total Hydrocarbons and E. coli. Results showed that, mainly during the first $45 \mathrm{~min}$ of the precipitation event, some levels of pollutants (e.g. Pb), can be high enough to cause serial disturbances in the Ria Formosa ecosystem and thus in human health.

Keywords: urban storm water, Mediterranean coastal city, climate change, EMC, urban pollutants.
\end{abstract}

\section{Introduction}

Ecosystems sustain societies that create economies. But although human beings are a product of the natural world, we have become the dominant force that shapes ecological and biophysical systems. Societies developed infrastructure projects, 
for instance, building large industrial and urban areas, particularly in coastal zones to have access to sea ports (ADB [1]). High concentration of people, infrastructures and economic activity mean that urban centres are highly exposed to natural hazards and climate change risks (WWF [2]). Sustainable urban water management is a great challenge to coastal cities, in the current scenario. This study was performed in Faro (Figure 1), which is a Mediterranean coastal city located at south of Portugal in Algarve region, near Ria Formosa.

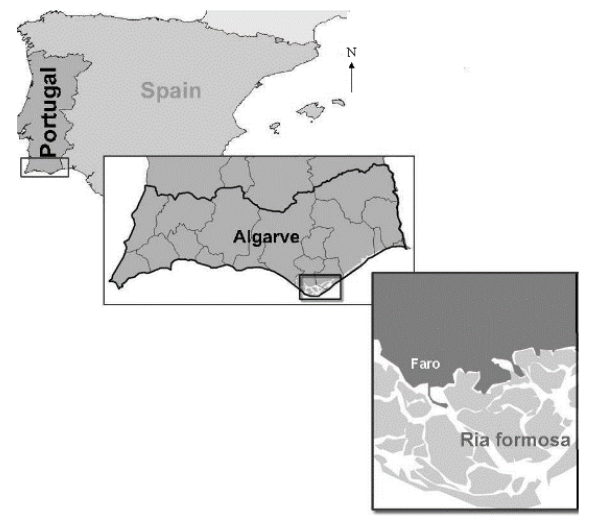

Figure 1: Location of Faro.

This coastal lagoon is a Natural Park with a relevant socio-economic role, associated to several activities, such as recreation, fisheries, salt extraction, and aquaculture, namely shellfish production. The city has a population of 44,119 , and the land use is mainly urban (INE [3]). The urban perimeter catchment has $4.7 \mathrm{~km}^{2}$, with an impervious surface of $96 \%$. The mean annual precipitation is $509.1 \mathrm{~mm}$ with a monthly variation between $1.9 \mathrm{~mm}$ (in July) and $115.6 \mathrm{~mm}$ (in December). The wet period is between October and April. The Köppen climate classification is Csa - a Mediterranean climate with rain being mostly regulated by frontal systems (Miranda [4]). The hydrological response of the basin is dominated by long dry periods followed by the wet season, in which rain events are usually short and intense. As presented in Figure 2, there are seven subcatchments linked to seven discharge points within the urban perimeter catchment.

There are no previous studies concerning urban storm water in Faro, therefore a methodology for all the different phases was developed following a multidiscipline effort.

\section{Methodology}

\subsection{Precipitation monitoring and meteorological forecast}

The precipitation was monitored by one rain gauge located at no longer than $5000 \mathrm{~m}$ from the farthest point of the catchment and it is characterised by a $0.1 \mathrm{~mm}$ tipping bucket and a temporal resolution of 1 minute. Meteorological 


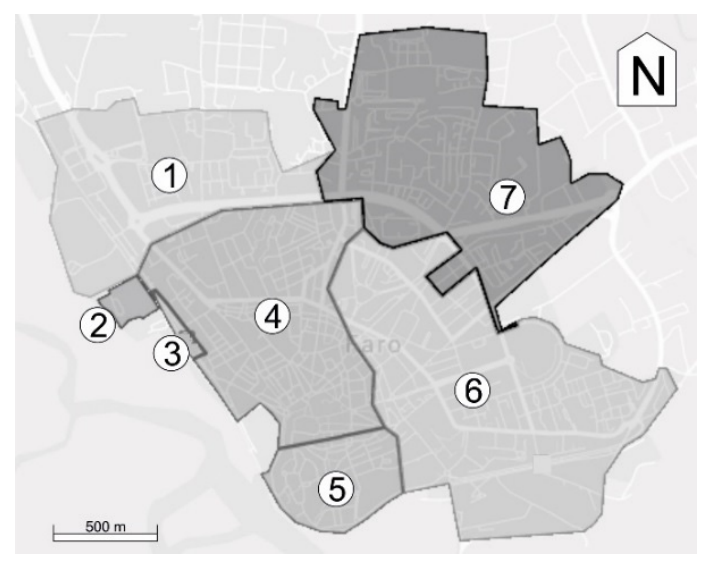

Figure 2: Urban perimeter SC (from 1 to 7 ).

forecast was made using the Global Forecast System - GFS numerical model with a resolution of $50 \mathrm{~km}$ (Kanamitsu et al. [5]), and the Weather Research and Forecast - WRF numerical model with a resolution of $9 \mathrm{~km}$ (Michalakes et al. [6]). It is not the intent of this study to detail these numerical models.

\subsection{Site selection}

The site selection was done using three criteria: accessibility, representativeness, and safety. Accessibility to the discharge points is a compulsory condition at all times, and is not possible at SC 2 because it's located on private property. Subcatchments 1, 3, 4, 6 and 7 can be accessed by paved roads. Sub-catchment 5 can only be accessed by water. Faro is considered a city with homogeneous land use, so representativeness was measured considering the relative area of the SC to the total area of the urban catchment. The relative areas were measured: SC $1(17.0 \%)$; SC 2 (0.9\%); SC 3 (0.5\%); SC 4 (20.0\%); SC 5 (5.6\%); SC $6(30.7 \%)$; and SC 7 (25.3\%). Concerning safety, and given the sloped access, SC 1, SC 2 and SC 7 have low risk of accident, SC 3, SC 4 and SC 6 have medium risk, and SC 5 has high risk, in this case depending on tides. The main sampling SC was chosen using the criteria mentioned above, in a three step exclusion scheme. The first exclusion step was the accessibility to sampling site, with SC 2 and SC 5 being excluded. On the second step, the combination of representativeness and safety was evaluated, and showed that SC 1, SC 3 and SC 4 should be excluded. On the third step all mentioned criteria were used. The two remaining sub-catchments, SC 6 and SC 7 have good accessibility and similar representativeness, but SC 7 has safer conditions, and was therefore chosen as the main sampling SC.

\subsection{Sampling}

A major storm of the 2014-2015 wet season was monitored on the 15 of January, 2015. Samples were collected every 15 min during the first hour after the rainfall event start, and then every $30 \mathrm{~min}$ until the end of the event. 


\subsection{Parameters}

The selected parameters were Total Suspended Solids (TSS), Total Nitrogen (TN), Total Phosphorus (TP), Chemical Oxygen Demand (COD), Biochemical Oxygen Demand (BOD), pH, Conductivity, Nickel (Ni), Cadmium (Cd), Lead (Pb), Total Hydrocarbons (TH) and Escherichia coli (E. coli) All analysis were performed by the Sanitary Engineering Laboratory of the University of the Algarve, accredited for water analysis (national code L0306), and analytical methods are presented in Table 1.

Table 1: Analytical methodology.

\begin{tabular}{|c|c|c|c|}
\hline Parameter & Unit & Method & Reference \\
\hline TN SMEWW & $\mathrm{mg} / \mathrm{L} \mathrm{N}$ & $\begin{array}{l}\text { Persulfate digestion and } \\
\text { Ultraviolet Spectrophotometric } \\
\text { Screening Method }\end{array}$ & Eaton et al. [7] \\
\hline Cd & $\mathrm{mg} / \mathrm{L} \mathrm{Cd}$ & $\begin{array}{l}\text { Flame Atomic Absorption: } \\
\text { Air-Acetylene Flame method }\end{array}$ & Eaton et al. [7] \\
\hline $\mathrm{BOD}_{5}, 2^{\circ} \mathrm{C}$ & $\mathrm{mg} / \mathrm{L} \mathrm{O}_{2}$ & Respirometric method & Eaton et al. [7] \\
\hline COD & $\mathrm{mg} / \mathrm{L} \mathrm{O}_{2}$ & Colorimetric method & Eaton et al. [7] \\
\hline $\mathbf{P b}$ & $\mathrm{mg} / \mathrm{L} \mathrm{Pb}$ & $\begin{array}{l}\text { Flame Atomic Absorption: } \\
\text { Air-Acetylene Flame method }\end{array}$ & Eaton et al. [7] \\
\hline Conductivity at $20^{\circ} \mathrm{C}$ in situ & $\mu \mathrm{S} / \mathrm{cm}$ & Electrometric method & Eaton et al. [7] \\
\hline Escherichia coli & $\mathrm{N} / 100 \mathrm{~mL}$ & Membrane filtration & ISO [8] \\
\hline TP & $\mathrm{mg} / \mathrm{L} \mathrm{P}$ & $\begin{array}{l}\text { Flame Molecular Absorption: } \\
\text { Ascorbic Acid Method }\end{array}$ & Eaton et al. [7] \\
\hline $\mathbf{N i}$ & $\mathrm{mg} / \mathrm{L} \mathrm{Ni}$ & $\begin{array}{l}\text { Flame Atomic Absorption: } \\
\text { Air-Acetylene Flame method }\end{array}$ & Eaton et al. [7] \\
\hline pH in situ & $\begin{array}{l}\text { Sorenson } \\
\text { scale }\end{array}$ & Electrometric method & Eaton et al. [7] \\
\hline TSS & $\mathrm{mg} / \mathrm{L}$ & Gravimetric method & Eaton et al. [7] \\
\hline TH & $\mathrm{mg} / \mathrm{L}$ & $\begin{array}{l}\text { Gas Chromatography: Flame } \\
\text { Ionization Detector }\end{array}$ & - \\
\hline
\end{tabular}

\subsection{Calculations}

Event Mean Concentration (EMC), determines pollutant loads from a site and is representative of average pollutant concentrations over an entire runoff event (Heart et al. [9]). The EMC is an important factor in predicting the total pollutant load, and therefore a critical parameter for estimating the contribution of runoff to the ecosystem (Maniquiz et al. [10]). EMC was determined using eqn. (1):

$$
E M C=\frac{M}{R}
$$

where:

$E M C=$ event mean concentration $(\mathrm{mg} / \mathrm{L})$;

$M=$ total discharged mass of pollutant (mg);

$R=$ total runoff volume $(\mathrm{L})$. 
Total discharged mass of pollutant (Load) was determined using a runoffweighted trapezoidal rule for numerical integration with a non-uniform grid (Atkinson [11]), as shown in eqn. (2):

$$
\begin{aligned}
\int_{R i}^{R f} f(R) \cdot d R \approx & \frac{1}{2} \sum_{k=1}^{N}\left|\left(R_{k+1}-R_{k}\right)\left(f\left(R_{k+1}\right)+f\left(R_{k}\right)\right)\right| \\
& =\frac{1}{2} \sum_{k=1}^{N}\left|\left(R_{k+1}-R_{k}\right)\left(C_{k+1}+C_{k}\right)\right|
\end{aligned}
$$

where:

$R i=$ initial runoff $(\mathrm{L})$;

$R f=$ final runoff $(\mathrm{L})$;

$R=$ accumulated runoff $(\mathrm{L})$;

$N=$ number of samples;

$k=$ sample number;

$C=$ pollutant concentration (units according to pollutant).

Runoff volume was determined using an adaptation of the Simple Method (McCarthy [12], Schueler [13]) with eqn. (3):

$$
R=P * R v
$$

where:

$R=\operatorname{runoff}(\mathrm{L})$;

$P=$ precipitation $(\mathrm{L})$;

$R v=$ runoff coefficient

Runoff coefficient was determined with eqn. (4):

$$
R v=0,05+0,9 I a
$$

where:

$R v=$ runoff coefficient;

$I a=$ percent impervious area draining to the sub-catchment in decimal form.

\section{Results and discussion}

\subsection{Characterization of the event}

The rainfall event lasted for $174 \mathrm{~min}$, having its maximum intensity peak of 20.4 $\mathrm{mm} / \mathrm{h}$ at $115 \mathrm{~min}$, and total accumulated rainfall of $12.7 \mathrm{~mm}$ (Figure 3).

\subsection{Evolution of pollutants during the event}

In general, there was a clear peak in pollutant concentrations in the first $31 \mathrm{~min}$ (16 min after runoff start) for all parameters except $E$. coli, which had the maximum peak later. These results indicate a typical first flush effect. The concentration of pollutants at the beginning of the event is substantially higher than during later periods (Lee et al. [14]). Runoff began 15 min after the rainfall 


\section{Precipitation}

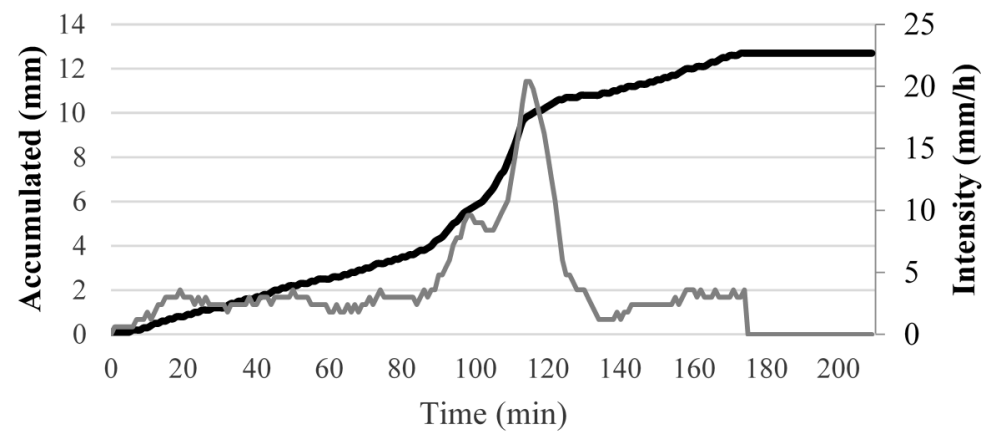

- Accumulated - Intensity

Figure 3: Hydrograph.

start. The results of the TSS, BOD and COD analysis are shown in Figure 4. According to previous studies in other urban areas (e.g. Lee et al. [15]), similar temporal evolutions of the TSS, BOD and COD were observed. Maximum concentration of TSS was $2507 \mathrm{mg} / \mathrm{L}$ at $31 \mathrm{~min}$ and minimum $50 \mathrm{mg} / \mathrm{L}$ at $209 \mathrm{~min}$. Concentrations of BOD and COD were maximum at 31 min with $500 \mathrm{mg} / \mathrm{L}$. Minimum values were obtained at $209 \mathrm{~min}, 22 \mathrm{mg} / \mathrm{L}$ for BOD and $40 \mathrm{mg} / \mathrm{L}$ for COD. Total suspended solids can be related to multiple sources, such as, pavement wear, construction sites, waste and atmospheric deposition, among others (Lee et al. [15], Barbosa et al. [16]), and can therefore be associated to BOD and COD values in different ways, according to the respective origins. Organic matter present in storm water is mainly of vegetal origin, but animal waste or dead organisms can also contribute to the BOD and COD values (Lee et al. [15], Barbosa et al. [16]).

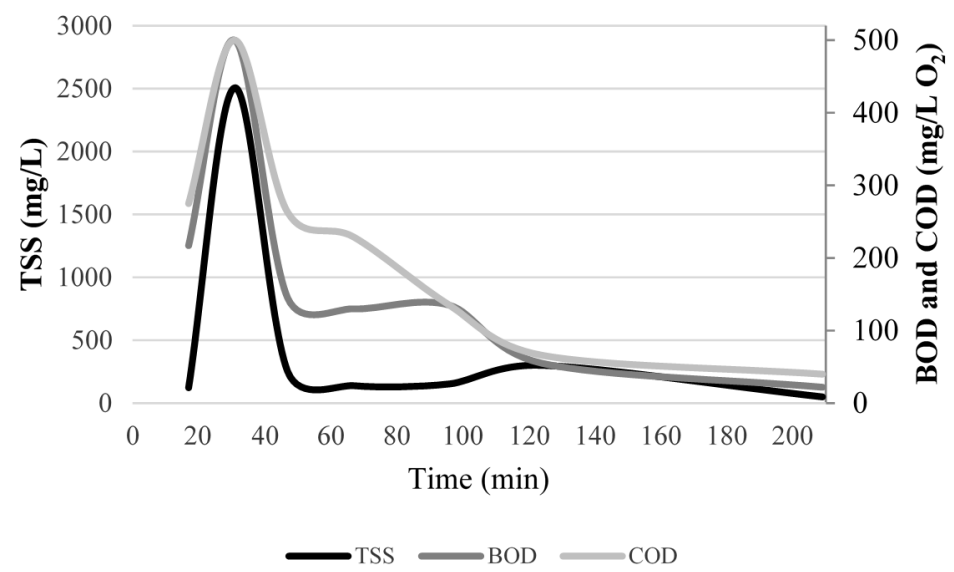

Figure 4: Evolution of TSS, BOD and COD. 
As previously demonstrated, e.g. in the French Mediterranean Coast (Obermann et al. [17]), TN and TP had similar behaviours during the event (Figure 5). Maximum concentrations of TN and TP occurred at $31 \mathrm{~min}, 72 \mathrm{mg} / \mathrm{L}$ and 19.2 $\mathrm{mg} / \mathrm{L}$ respectively, and minimum at $209 \mathrm{~min}, 3 \mathrm{mg} / \mathrm{L}$ and $0.8 \mathrm{mg} / \mathrm{L}$, respectively. In the case of TN at $124 \mathrm{~min}$, another minimum value of $3 \mathrm{mg} / \mathrm{L}$ was observed.
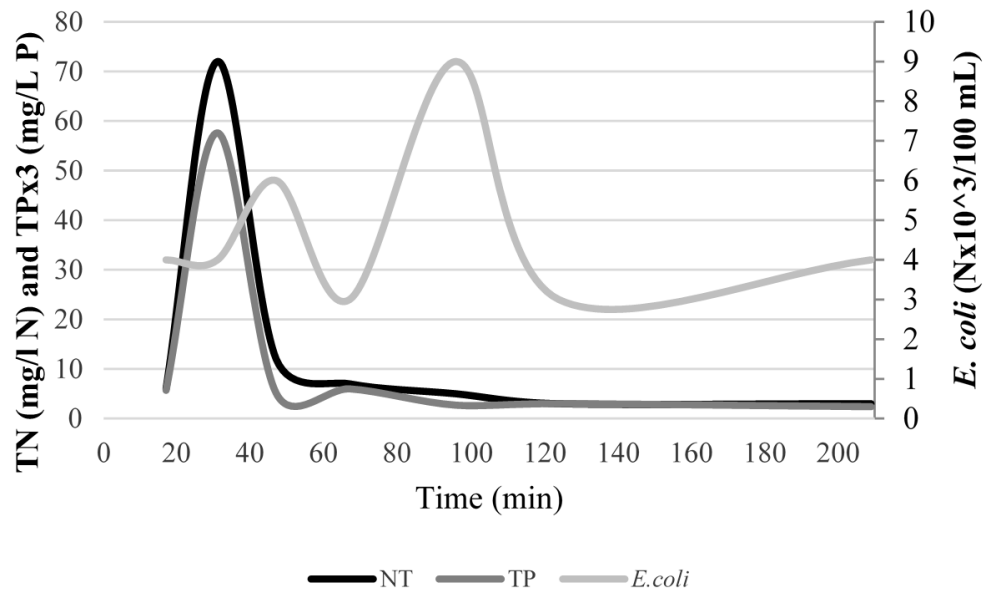

Figure 5: $\quad$ Evolution of TN, TP and E. coli.

The most important sources of $\mathrm{N}$ and $\mathrm{P}$ in urban areas, are atmospheric deposition and fertilizers used in the treatment of urban green areas (Lee et al. [15], Barbosa et al. [16]). In terms of microbiological results, the first peak of $E$. coli occurred at $47 \mathrm{~min}$, which can be related to the first flush effect, followed by a decreasing to $3 \times 103 \mathrm{~N} / 100 \mathrm{~mL}$ at $67 \mathrm{~min}$. At $96 \mathrm{~min}$, during a peak of rainfall intensity, a second maximum of E. coli $(9 \times 103 \mathrm{~N} / 100 \mathrm{~mL})$ occurred, perhaps due to a non-authorized wastewater discharge to the storm water system. Wastewater cross connections, leakages and overflows are common origins of E. coli, when precipitation intensity peaks exist (McCarthy et al. [18]). According to previous studies (House et al. [19], D'Arcy et al. [20], Moy et al. [21], Ellis and Mitchell [22]), E. coli in the UK ranges between 400 and 50,000 MPN/100 mL, associated with specific urban land use types and surfaces. The temporal evolution pattern of Conductivity was according to the first flush effect, with a maximum of $430 \mu \mathrm{S} / \mathrm{cm}$ at $31 \mathrm{~min}$, and a minimum of $66 \mu \mathrm{S} / \mathrm{cm}$ at $124 \mathrm{~min}$ (Figure 6). Cadmium, Ni and $\mathrm{Pb}$ had similar variations during the event, with some particular differences, namely to $\mathrm{Pb}$. The maximum of $\mathrm{Pb}$ concentration was $93.42 \mu \mathrm{g} / \mathrm{L}$ at the beginning of the event, followed by a decreasing. A second peak of $\mathrm{Pb}$ occurred at $124 \mathrm{~min}$. The minimum concentration of $\mathrm{Pb}$ was $7.77 \mu \mathrm{g} / \mathrm{L}$ and was observed at the end of runoff. The first flush effect was clearly noticed also on $\mathrm{Ni}$ and $\mathrm{Cd}$ concentrations. Maximums were at $31 \mathrm{~min}$, with $21.56 \mu \mathrm{g} / \mathrm{L} \mathrm{Ni}$ and $2.32 \mu \mathrm{g} / \mathrm{L} \mathrm{Cd}$. The minimum concentrations occurred from $96 \mathrm{~min}$ to $\mathrm{Ni}(4.96 \mu \mathrm{g} / \mathrm{L})$ and from $124 \mathrm{~min}$ to $\mathrm{Cd}$ $(0.56 \mu \mathrm{g} / \mathrm{L})$. In general, $\mathrm{Cd}, \mathrm{Ni}$ and $\mathrm{Pb}$ have the same sources: tire wear, lubricating oils, fuel, and diverse metallic structures such as road signs, roofs or covers 
(Barbosa et al. [16], Gikas and Tsihrintzis [23]). In this study, according to official data, the main anthropic pressures associated to the presence of heavy metals, are traffic and urbanization.
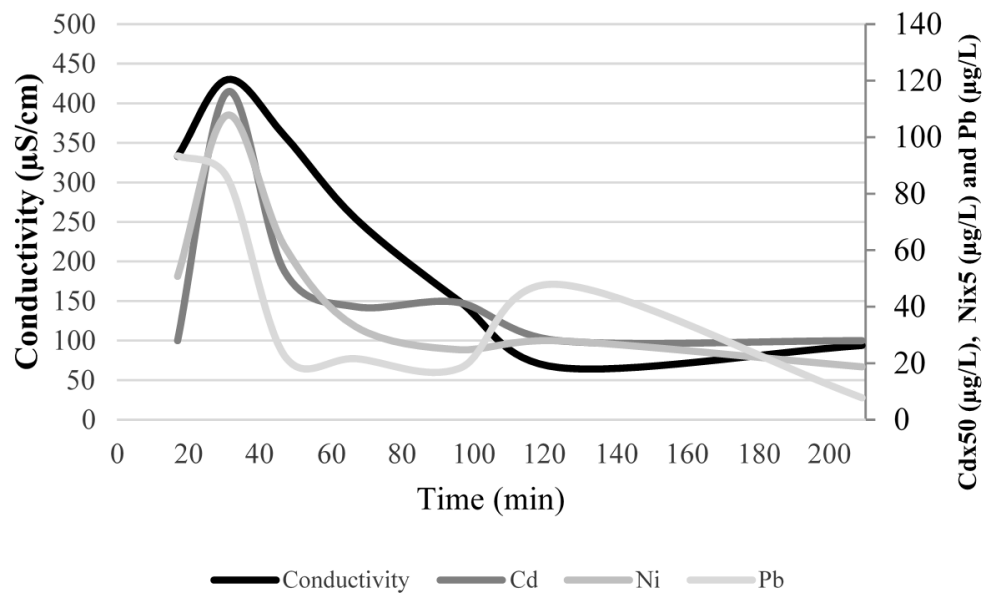

Figure 6: Evolution of Conductivity, $\mathrm{Ni}, \mathrm{Cd}$ and $\mathrm{Pb}$.

Total Hydrocarbons (C10-C40) were lower than $0.1 \mathrm{mg} / \mathrm{L}$ (Limit of Quantification) during all event. Main sources of TH in urban basins are fossil fuel combustion, road and pavement wear, tire wear, and plastic materials from construction, or other temporary structures (Lee et al. [15], Barbosa et al. [16]). During this event, $\mathrm{pH}$ ranged between 7.1 and 8.0, which are common values to surface waters (Smith [24]). Event Mean Concentrations and loads were calculated and are presented in Table 2.

Table 2: Pollutant concentrations and loadings.

\begin{tabular}{ccccc}
\hline \multicolumn{3}{c}{ Sub-catchment 7} & $\begin{array}{c}\text { Urban } \\
\text { perimeter } \\
\text { catchment }\end{array}$ \\
\hline Parameter & EMC (mg/L) & $\begin{array}{c}\text { Load } \\
(\mathbf{k g})\end{array}$ & $\begin{array}{c}\text { Load per } \\
\text { unit area } \\
\left(\mathbf{k g} / \mathbf{k m}^{2}\right)\end{array}$ & Load (kg) \\
\hline TSS & 316 & 4661 & 3950 & 18565 \\
TN & 9 & 126 & 107 & 502 \\
TP & 2.1 & 32 & 27.12 & 127 \\
Ni & $6.73 \times 10^{\wedge}-3$ & 0.099 & 0.084 & 0.394 \\
Cd & $0.79 \times 10^{\wedge}-3$ & 0.012 & 0.010 & 0.048 \\
Pb & $33.46 \times 10^{\wedge}-3$ & 0.493 & 0.418 & 2 \\
TH & $<0.1$ & -- & -- & -- \\
E. coli & $4 \times 10^{\wedge} 3$ & -- & -- & -- \\
\hline
\end{tabular}




\subsection{Pollutant concentrations and loadings}

The EMC's for different parameters monitored during this event, were compared with EMC's from previous studies (McCarthy et al. [18], Ellis and Mitchell [22], Brezonik and Stadelmann [25] and Mitchell [26]), despite the different climate classification of the studied cities. Total Suspended Solids, TN and TP had higher EMC's than the UK (Ellis and Mitchell [22]) and the Twin Cities, USA (Brezonik and Stadelmann [25]). Nickel, $\mathrm{Cd}$ and $\mathrm{Pb}$ presented lower EMC's than those quantified by Mitchell [26], and in case of $\mathrm{Pb}$ also by Ellis and Mitchell [22]. The E. coli EMC is lower than that described by Ellis and Mitchell [22] and McCarthy et al. [18]. The EMC values obtained can be overestimated or underestimated (eqn. (1)), which might lead to considerable variations depending on the event monitored. These variations are reported in several studies (Maniquiz et al. [10], Lee et al. [15], McCarthy et al. [18], Bi et al. [27], Maniquiz et al. [28] and Ellis and Chatfield [29]).

In an environmental perspective, loads per unit area were calculated for SC 7, and then estimated to the entire urban catchment to access the quantity of pollutants discharged to Ria Formosa. During this event, it was shown that, even parameters with low EMC's can represent risk to natural ecosystems and human health (e.g. Pb).

\section{Conclusions}

Results showed that, mainly during the first $45 \mathrm{~min}$ of the precipitation event, some levels of pollutants (e.g. $\mathrm{Pb}$ ), can be high enough to cause serial disturbances in environment and human health. The risk can be higher in a scenario of climate changes, in which coastal Mediterranean cities like Faro are particularly vulnerable to extreme precipitation phenomena, occurring even more frequently. In the case of Faro, all pollutants are discharged directly to Ria Formosa, which is a Natural Park, considered of main importance to habitats and biodiversity, but also to local economy. An integrated urban water management plan should be developed, with tools and measures, supported by scientific studies to monitor storms. Mediterranean coastal cities should implement technological solutions like first flush treatment to reduce the pollution loads from storm runoff, and to achieve sustainable development.

\section{References}

[1] Asian Development Bank (ADB), Moving from Risk to Resilience Sustainable Urban Development in the Pacific. Asian Development Bank Report, Manila, 2013.

[2] World Wildlife Fund (WWF), Living Planet Report 2014, WWF Report, Gland, 2014.

[3] Portuguese National Statistics Institute (INE), Anuário Estatístico da Região do Algarve 2012, INE Report, Lisbon, pp. 131-175, 2013. 
[4] Miranda P.M., Meteorologia e Ambiente, Universidade Aberta: Lisboa, pp. 249-255, 2001.

[5] Kanamitsu, M., Alpert, J.C., Campana K.A., Caplan P.M., Deaven D.G, Iredell M., Katz B., Pan H.L., Sela J. \& White G.H., Recent changes implemented into the global forecast system at NMC. Weather and Forecasting, 6, pp. 425-435, 1991.

[6] Michalakes, J., Dudhia J., Gill D., Klemp J. \& Skamarock W., Design of a next-generation regional weather research and forecast model: Towards Teracomputing. World Scientific, pp. 117-124, 1998.

[7] Eaton A.D., Clesceri L.S., Rice E. \& Greenberg A., Standard Methods for the Examination of Water and Wastewater $21^{\text {st }}$ edition, American Public Health Association, American Water Works Association and Water Environmental Federation: Washington, 2005.

[8] International Organization for Standardization (ISO), ISO 9308-1: Water Quality - Detection and enumeration of Escherichia coli and coliform bacteria, ISO: Geneva, 2000.

[9] Heart, R.G., Horner, R., Jones, J., Josselyn, M., Pitt, R. \& Stenstrom, M.K., Sample Collection Methods for Runoff Characterization at Santa Susana Field Laboratory, SSFL CDO Expert Panel Report, Santa Susana, 2008.

[10] Maniquiz M.C., Choy J., Lee S., Cho H.J.\& Kim L., Appropriate Methods in Determining the Event Mean Concentration and Pollutant Removal Efficiency of a Best Management Practice, Environmental Engineering Research, 15(4), pp. 215-223, 2010.

[11] Atkinson, K., An Introduction to Numerical Analysis (2nd ed.), John Wiley \& Sons: New York, 1989.

[12] McCarthy, J., Pollutant Loading Calculations - The Simple Method. New Hampshire Stormwater Manual, 1, pp. 80-85, 2008.

[13] Schueler T., Controlling Urban Runoff: A Practical Manual for Planning and Designing Urban Best Management Practices. Metropolitan Washington Council of Governments Report, 1987.

[14] Lee J.H., Bang K.W., Ketchum L.H., Choe J.S. \& Yu M.J., First flush analysis of urban storm runoff. The Science of the Total Environment, 293, pp. 163-175, 2002.

[15] Lee, J. Y., Kim, H., Kim, Y. \& Han, M. Y., Characteristics of the event mean concentration (EMC) from rainfall runoff on an urban highway. Environmental Pollution, 159, pp. 884-888, 2011.

[16] Barbosa, A.E., Fernandes, J.N. \& David, L.M., Key issues for sustainable urban stormwater management. Water Research, 46, pp. 6787-6798, 2012.

[17] Obermann M., Rosenwinkel, K. \& Tournud, M., Investigation of first flushes in a medium-sized Mediterranean catchment. Journal of Hydrology, 373, pp. 405-415, 2009.

[18] McCarthy, D.T., Hathaway, J.M., Hunt, W.F. \& Deletic, A., Intra-event variability of Escherichia coli and total suspended solids in urban stormwater runoff. Water Research, 46, pp. 6661-6670, 2012.

[19] House, M.A., Ellis, J.B., Herricks, E.E., Hvitved-Jacobsen, T., Seager, J., Lijklema, L., Aalderink, H. \& Clifforde, I.T., Urban Drainage: Impacts on 
Receiving Water Quality. Water Science Technology, 27 (12), pp. 117-158, 1993.

[20] D’Arcy, J.B., Ellis, J.B., Ferrier, R.C., Jenkins, A. \& Dils, R., (eds). Diffuse Pollution Impacts: The Environmental and Economic Effects of Diffuse Pollution in the UK. Terence Dalton Publishers. Ltd.: Lavenham, 2000.

[21] Moy, F., Crabtree, R. \& Simms, T. Long term monitoring of pollution from highway runoff. Environment Agency R\&D Report No. P2-038, WRC: Swindon, 2003.

[22] Ellis, J.B. \& Mitchell, G., Urban diffuse pollution: key data information approaches for the Water Framework Directive. Water and Environment Journal, 20, pp. 19-26, 2006.

[23] Gikas G.D. \& Tsihrintzis V.A., Assessment of water quality of first-flush roof runoff and harvested rainwater. Journal of Hydrology, 466-467, pp. 115-126, 2012.

[24] Smith, E., 2001, Pollutant concentrations of stormwater and captured sediment in flood control sumps draining an urban watershed. Water Research, 35(13), pp. 3117-3126, 2001.

[25] Brezonik, P.L. \& Stadelmann, T.H., Analysis and predictive models of stormwater runoff volumes, loads, and pollutant concentrations from watersheds in the Twin Cities metropolitan area, Minnesota, USA. Water Research, 36, pp. 1743-1757, 2002.

[26] Mitchell, G., Mapping hazard from urban non-point pollution: a screening model to support sustainable urban drainage planning. Journal of Environmental Management, 74, pp. 1-9, 2005.

[27] Bi, E.G., Monette, F. \& Gasperi, J., Analysis of the influence of rainfall variables on urban effluents concentrations and fluxes in wet weather. Journal of Hydrology, 523, pp. 320-332, 2015.

[28] Maniquiz, M.C., Lee, S. \& Kim, L., Multiple linear regression models of urban runoff pollutant load and event mean concentration considering rainfall variables. Journal of Environmental Sciences, 22(6), pp. 946-952, 2010.

[29] Ellis, J.B. \& Chatfield, P.R., Diffuse urban oil pollution in the UK. Urban Water Journal, 3(3), pp. 165-173, 2006. 